\title{
New perspectives for landscape architecture in Russia - Park Zaryadye in Moscow
}

\author{
Nickolay Vladimirovich Kasyanov, Scientific Research Institute of Theory of Architecture and \\ Urban Planning (NIITIAG), Moscow, Russia
}

\begin{abstract}
The article considers a recent large-scale landscape-architectural experiment in the historical centre of Moscow. Zaryadye district, mentioned since the XII century, has a rich history, and the most dynamic changes occurred in the XX century, when historical buildings were demolished and several architectural projects of Soviet gigantomania were subsequently tried to realize in this area. By 2010 this territory in the centre of the Moscow turned into a wasteland. By September 2017 a landscape-architectural park was created here according to the project of the American firm Diller Scofidio + Renfro, which won the competition. The park implements an artificial relief, in which a miniature display of different Russian landscapes is integrated with buildings of various cultural purposes. As a result, the sudden transformation of a considerable territory near the Kremlin appeared, and new unexpected and interesting visual landscapes opened. One of the goals is to present a new park to landscape architects and researchers.
\end{abstract}

Keywords: landscape architecture, urban landscape, landscape change, multifunctional park, Moscow, park "Zaryadye"

\section{Introduction}

The work was carried out to explore a new landscape architectural artifact in the centre of Moscow. It should be noted that the work of the Diller Scofidio + Renfro bureau is quite original and innovative, for example, the popular New York High Line park, which was created on the site of the former railway line in Manhattan in 2009 [8]. Park "Zaryadye" (Парк «Зарядье») is the first such large object of urban landscape design in Russia. There are no direct analogs to such a park, but its elements can be compared with some projects of recent years, for example, underground or semiunderground architectural landscape structures, which are quite popular in Europe. So, many buildings can recall works of the architect Peter Vetsch (the Vetsch Architektur bureau), of the architect Friedensreich Regentag Dunkelbunt Hundertwasser or "House of Spiritual Retreat" (Casa de Retiro Espiritual, 2005) [11] of Emilio Ambasch [3], and many others. Trends of sustainable development, ecologization and attempts to humanize the environment on the background of globalization and urbanization are developing, landscape parks integrated into the megacities in different regions from America to South-East Asia are emerging.

Landscape architecture is a dynamic, multidisciplinary field, incorporating architecture, construction, engineering, ecology, garden art and efficiently enhancing the quality of life for the people, protecting the natural environment and saving landscape resources. John Ormsbee Simonds was one of the most influential and well-known

figures in landscape architecture in XX century. He was an environmentalist, professor, and an author of numerous scientific works including the classic "Landscape Architecture" [6], which successfully withstands the test of time, remaining the basic resource for landscape designers. Following books written by M. Laurie, 1975 [5], Alexander et al., 1977 [1], Thompson and Sorvig, 2008 [9] provided data on landscape architecture, environmental design, ecological planning, buildings and construction. Alexander et al., 1977 [1] considered the variety of designs as the realization of a pattern language. Thompson and Sorvig, 2008 [9] argue that the sustainability of ecosystems is a central theme in landscape architecture. J. Steele in his book (1977) [7] interpreted sustainable architecture as the connection between ecological "green" design and sustainable development in countries.

\section{Material and Methods}

The author fulfilled field surveys, photographic fixation, study of different data including printed scientific publications and electronic resources addressing landscape architecture and related topics; descriptive and comparative analysis of the obtained results, using a number of graphic programs and computer tools to create an original schematic map of the park spaces based on cartographic services as well as information materials of the park. The methods used in the construction of the park in Zaryad'e are partially considered in the main text. 


\section{Results and discussions}

This project implemented an attempt to create an islet of nature in the middle of a metropolis, which corresponds to global trends. The very possibility of its appearance allows us to hope for the emergence of other landscape-architectural parks in the urbanized environment.

In the fall of 2017, an unusual landscape architectural park, "Zaryadye" (Парк «Зарядье») was opened in the historical centre of Russian capital. The idea of this object, like its current virtual reality, emerged almost suddenly and was realized relatively quickly. Even at the stage of its project, there was a certain excitement in the society and the media, which reached its apogee after the opening of the park, with positive reviews prevailing in the mass media. This article aims describe the sudden transformation of a considerable territory near the Kremlin and the opening of new visual landscapes in the centre of Moscow.

In Moscow, with its twelve administrative districts, including the new territories, there are about 130 different gardens, parks and squares. "Zaryadye" park is located in the heart of Moscow, near Kremlin; between Varvarka street, Kitay-Gorod, Moskva-river embankment; the nearest metro stations are "Kitay-Gorod" and "Revolution Square". A free entrance from all streets around the park is available each day during 24 hours.

"Zaryadye" is mentioned in written sources from the middle of the XII century [20]. In the 1930s, in Zaryadye it was planned to erect a high-altitude building of the People's Commissariat (Ministry) of heavy industry; many historical buildings and temples were demolished. In 1964, on the foundation of the People's Commissariat the construction of the hotel "Russia" began under the project of D. Chechulin. By the 1990s, the hotel, which had not been modernized for a long time, began to bear losses and was closed in 2006.

Several years ago, a somewhat unexpected for Russia idea of a landscape architectural experiment in Zaryadye emerged. Announced competition for the best concept of the park gathered 87 applications from more than 400 companies from 27 countries. In 2013, the first stage of the competition was held. In the second stage of the competition, six consortiums were selected. The winner of the competition became an international consortium from the Bureau of Diller Scofidio + Renfro, Hargreaves Associates and Citymakers [8]. The studio was founded by Elizabeth Diller and Ricardo Scofidio in 1979. Diller Scofidio + Renfro, based in New York City, is an interdisciplinary design studio that integrates architecture, the visual arts, and the performing arts [2].

The authors of the concept of a new park, assuming the maximum fusion of the urban environment with wildlife, defined it as "wild" or "natural" urbanism. "Our idea is to return the nature to the inhabitants of the city. Every city should have a place where people can relax... Here, people will not be separated from nature...", Elizabeth Diller said. In their concept, architects combined the Kremlin with different types of natural landscapes in Russia, such as the northern tundra, taiga, other forests and meadows, with separate microclimate for everyone [12].

Construction of the park "Zaryadye" began in 2015. To create the park's natural areas, 250 thousand cubic meters of new soil were imported. During the monolithic works more than 100 thousand cubic meters of concrete will be used. The total area of the constructed buildings will be almost 79 thousand square meters. The designed way network has a length of $9 \mathrm{~km}$. Among the priority tasks in the tender documentation was the preservation of the relief with a height difference, as the creation of a system of terraces without tall buildings due to the location next to the UNESCO World Heritage sites - the Moscow Kremlin and Red Square [21]. An important element of the project is that routes are not prescribed, and visitors will be able to navigate the park as desired.

The timing of the delivery of such complex and large-scale facility was quite tough. The park was built in 2,5 years; more than five thousand people worked here all day and night. During this time, near the Kremlin walls forests and meadows, a "Glass Crust" and other constructions emerged, mostly locating underground (Fig. 1). The park was inaugurated on September 9, 2017 on the City Day, the 870th anniversary of Moscow. During the first week more than 250 thousand citizens visited "Zaryadye". On weekdays, the park was visited by 10-30 thousand people. Expected, that the park "Zaryadye" will be visited by 10-12 million people a year [17].

The recreation zone emerged near the very walls of the Kremlin. "Zaryadye" park is a miniature display of Russia's landscapes. The total area of the park is more than 13 hectares, the park itself occupies an area of 10.2 hectares. The total area of the objects is more than 80 thousand square meters [18]. The park represents the main landscape and climatic zones of Russia: the northern tundra, coniferous and mixed forests, birch groves, coastal forest (Fig. 2), meadows, mini-lakes (Fig. 3) with aquatic plants. Landscapes are terraces, 


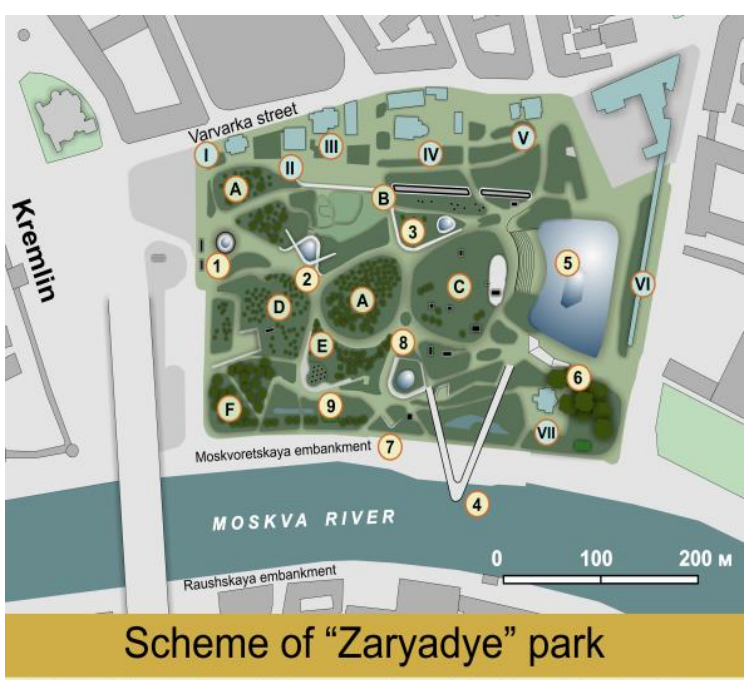

1. Dome; 2. Media Center; 3. Reserve Ambassy \& Ice Cave; 4. Soaring Bridge; 5. Glass Crust, Big Amphitheater \& Concert Hall; 6. Small Amphitheater; 7. Underground Museum; 8. Café; 9 . Restaurant

A. Birch Forest; B. Nothern Landscapes; C. Meadow; D. Mixed Forest; E. Coniferous Forest; F. Coastal Forest

I. Church of Great Martyr Barbara in Varvarka; II. Old English Court Museum; III. Saint Maximus's church; IV. Cathedral of Znamensky Monastery; V. Church of Saint George the Victorious; VI. Fragment of the Kitay-gorod wall; VII. Church of the Conception of St Anne

Fig. 1. Schematic plan of the "Zaryadye" park [created by the author]

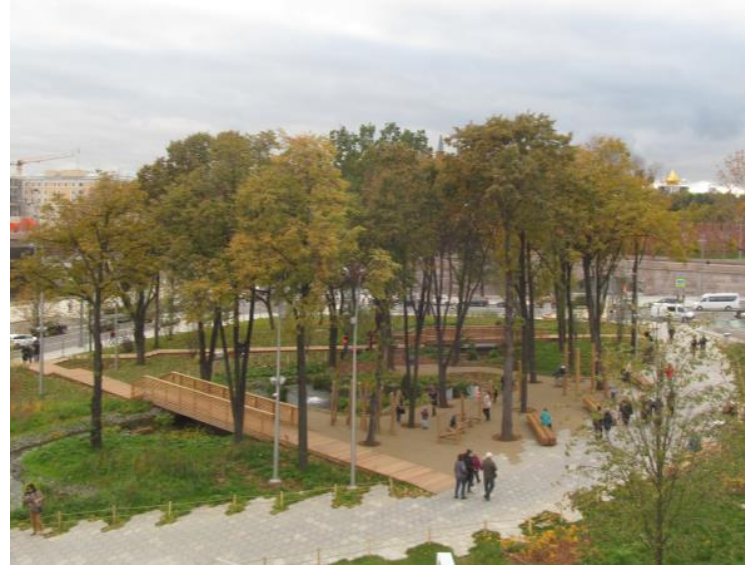

Fig. 2. View of the "coastal forest" [photo by the author]

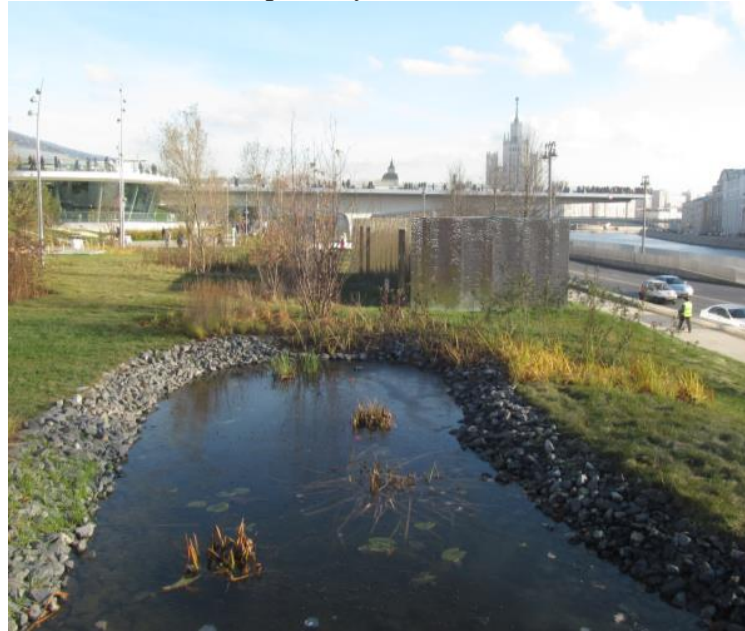

Fig. 3. One of the ponds [photo by the author]

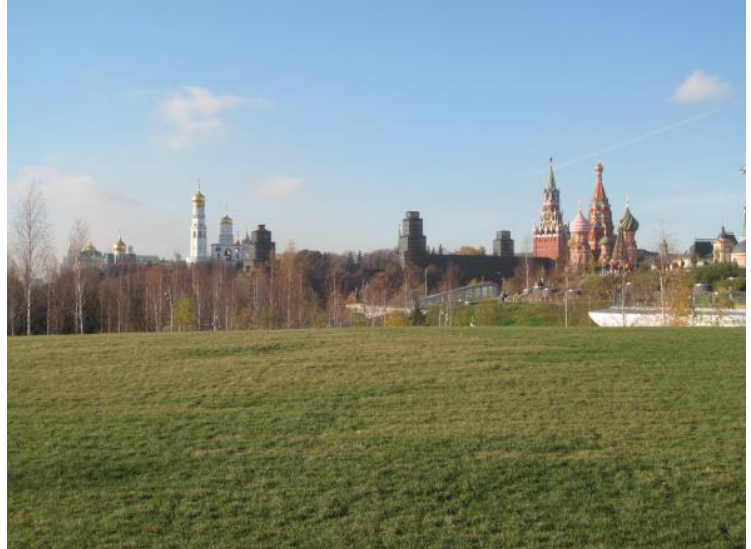

Fig. 4. Unusual panorama of the city centre [photo by the author]

successively descending from the upper level of the site to its lower part (from the north-east to southwest), intersecting and overlapping. Approximately 750 trees, 7000 shrubs, more than 850 thousand perennial flowers, about 150 thousand annual flowers are planted here. In the "Zaryadye" park there were about 120 species of native plants, even plants from the Red Book of Moscow. An additional planting out of 450 thousand plants is planned. In addition, a separate zone of ponds (in place of the former bed of the Neglinka River) has been constructed [17]. Young willows, irises and forget-me-nots were planted along the banks; snow-white water-lilies and reeds appeared in the reservoirs. For the convenience of the visitors of the park, wooden bridges are thrown across the ponds.

Thus, in Zaryadye an artificial relief with unique landscapes, lowlands and hills formed, from which new, unexpected picturesque views are opened. From the tops of the hills you can see the Kremlin, Red Square, St. Basil's Cathedral and the high-rise building on Kotelnicheskaya embankment, as well as the monuments of Zaryadye itself, restored during the creation of the park. In addition, the "Glass Crust" with large amphitheater is best seen from here, from the park it looks like a glass-covered mountain with the amphitheater on a slope. New visual panoramas are opened because buildings in the park mostly are hidden under the landscape (Fig. 4). In essence, the park exploits roofs of buildings [14]. At the same time, "Zaryadye" is a cultural and educational centre with complicated architectural objects, a fairy town with houses-hills, each of which is a multifunctional pavilion. It is simultaneously a park, a city square, and a cultural landmark.

Sometimes a similarity between "Zaryadye" and High Line Park in Manhattan in New York and European parks was found, but the uniqueness of the "Zaryadya" landscape is in its botanical collection, represented by plants from different parts of Russia. Such a variety of plants, revealing the country's natural diversity, is nowhere else. At the same time 
it is a territory of silence, tranquility, recreation [14]. It is necessary more comprehensive description of main architectural objects of the park. Near the entrance to the park "Zaryadye" from the side of Vasilievsky descent there is an information pavilion "Dome". The pavilion is equipped with a set of QRcodes (on walls and ceiling); activating QR-codes with a smartphone or tablet, you can get information about the territory and objects of "Zaryadye" park. The "Dome" is an allusion of Russian Pavilion at the Venice, received a prize at the Venice Architectural Biennale in 2012 [4]. The pavilion symbolized the innovative centre Skolkovo, a modern scientific and technological complex, the first science city built in the post-Soviet Russia.

In the multifunctional interactive complex "Media Center" (Fig. 5) there are also 14 small service places around the park where you can buy or order tickets for exhibitions or master classes.

The white colouring of the outer walls of the pavilions, "half-buried" in the ground, emphasizes the plasticity of concrete "casting"; in sunlight an interesting play of light appears.

In the "Media Center", you can show threedimensional films accompanied by additional "presence effects". The "Flight over Russia" attraction using a huge parabolic screen and chairs on a mobile platform, creates the illusion of soaring above the earth surface; multichannel sound and special effects in the form of water spray, wind generators, smoke and smells simulate the geyser sprays, wind flow, volcanic heat and smoke, smells. Before the eyes of spectators, the active volcano in Kamchatka, fantastic stone columns in Komi appear. Another attraction film, "The Time Machine Zaryadye", using the panoramic screen with a projection of 360 degrees and 5 meters high as "Time Machine", transfer you to the tenth century when the tribe of Vyatichi lived on the banks of the Moscow and Neglinnaya rivers, surrounded by impenetrable forests [17].

The educational centre "Reserve Ambassy" (Fig. 6) includes a scientific centre with lecture halls for lectures and experiments, classes in genetics, biotechnology, microbiology, geography and ecology. During the construction of the underground passage, some disassembled stones of the ancient wall of the Kitay-gorod were moved to the "Reserve Ambassy" for finishing the main entrance wall [14].

In the hall of "Media Center" there is a florarium (Fig. 7) - a hothouse complex under a glass roof for growing more than 500 species of tropical plants using hydroponics, that is, without soil, on the basis of a complex engineering system for preparing nutrient solutions and feeding the root system of plants [16].

On the area of the "Reserve Ambassy", which is 3,300 square meters, there is also the "Ice Cave"

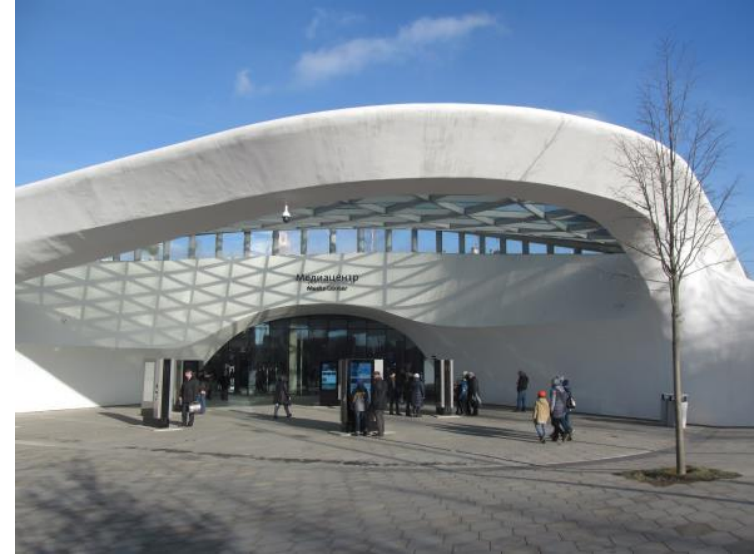

Fig. 5. The entrance in the "Media Center" [photo by the author]

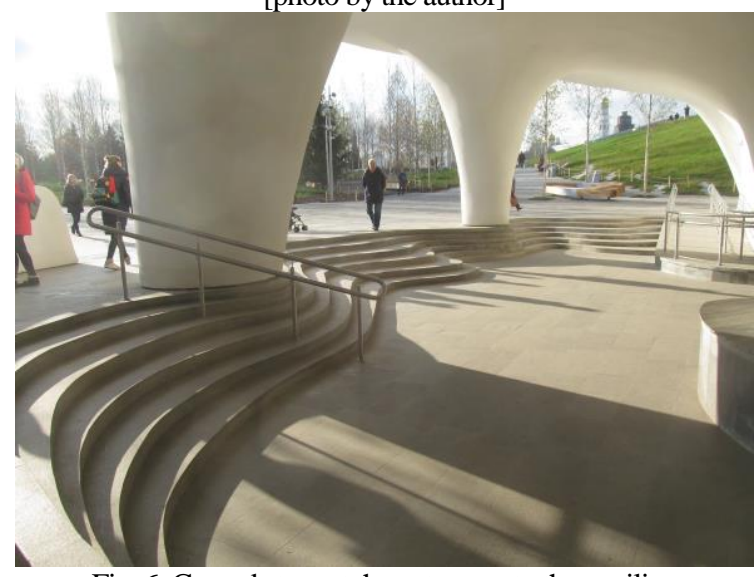

Fig. 6. Curved steps at the entrances to the pavilion "Reserve Ambassy" [photo by the author]

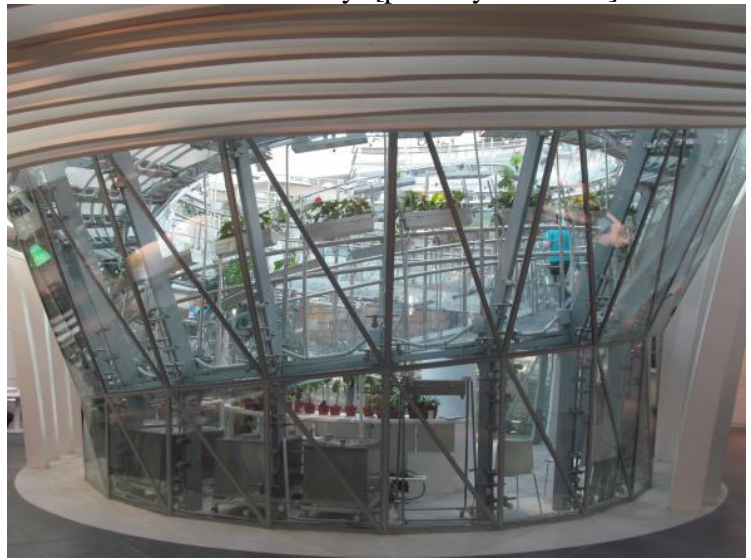

Fig. 7. "Florarium" in the "Reserve Ambassy" [photo by the author]

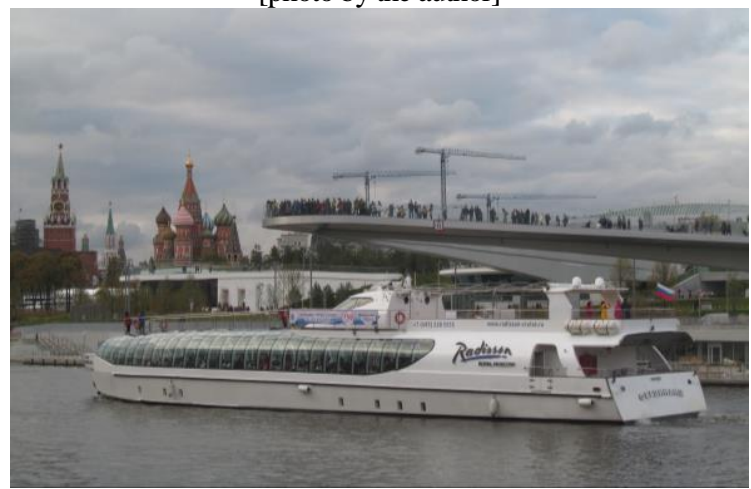

Fig. 8. A view of the "Soaring Bridge" from the Raushskaya embankment [photo by the author] 

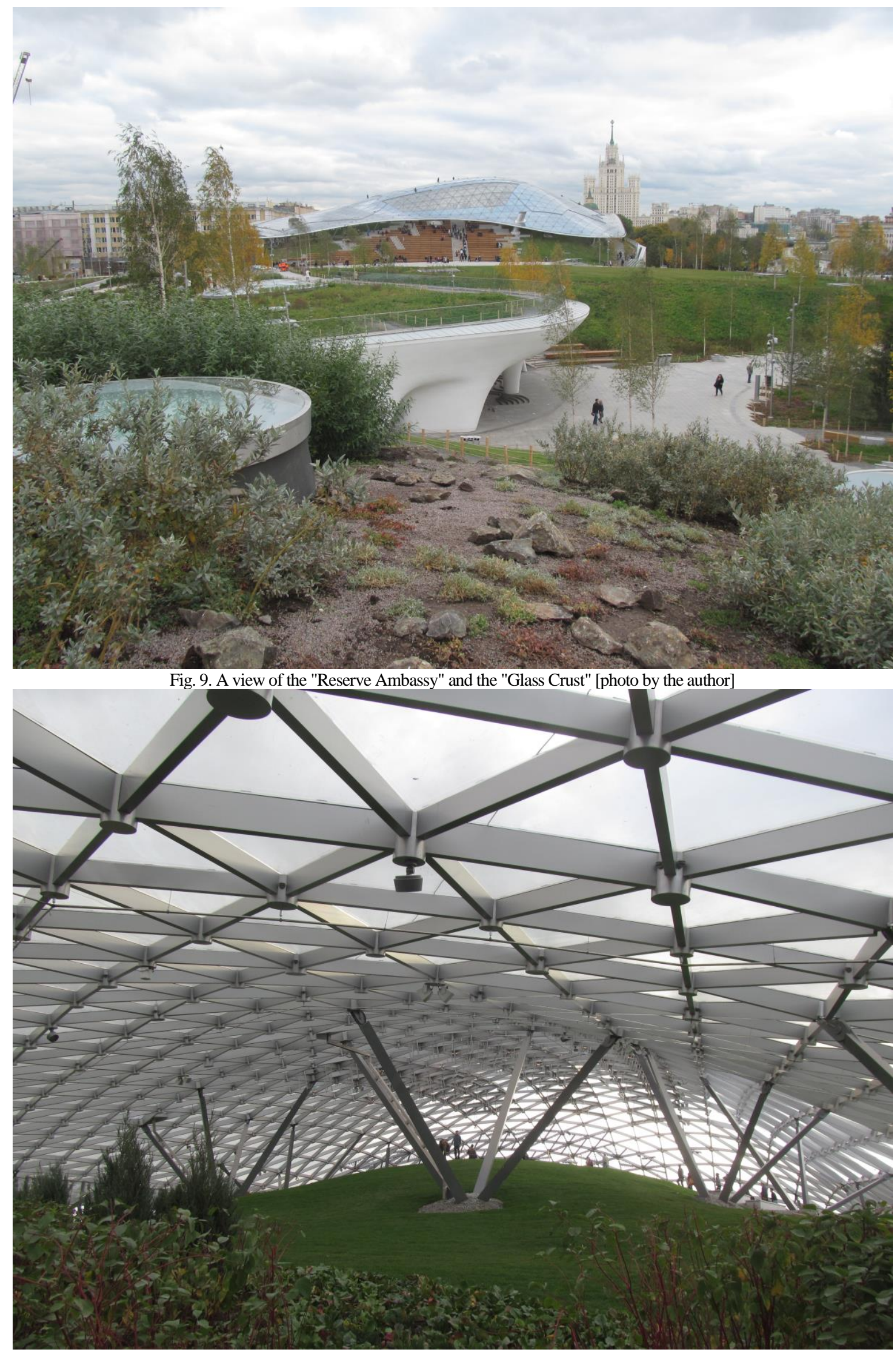

Fig. 10. "Glass Crust" from the inside [photo by the author] 


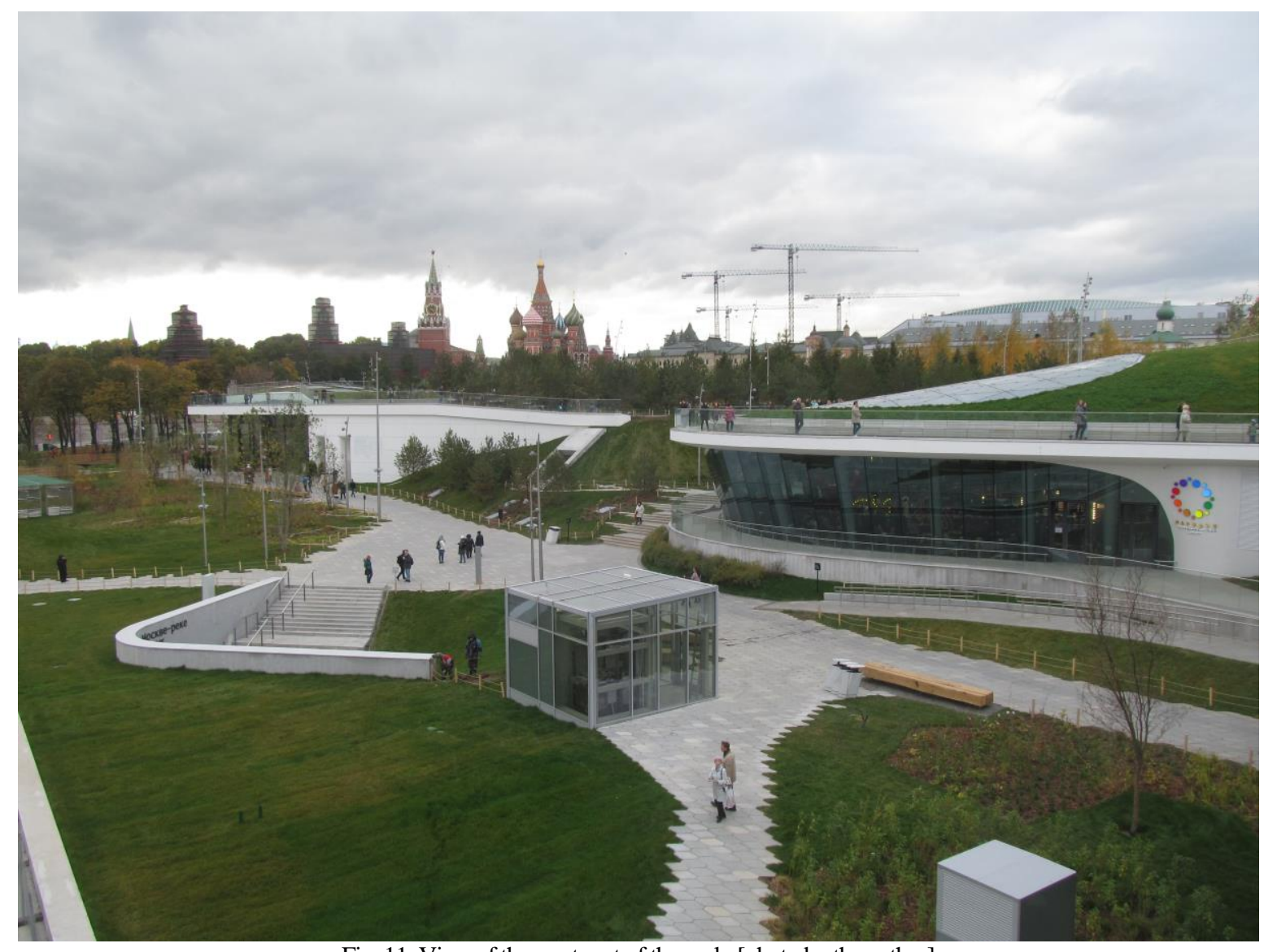

Fig. 11. View of the west part of the park [photo by the author]

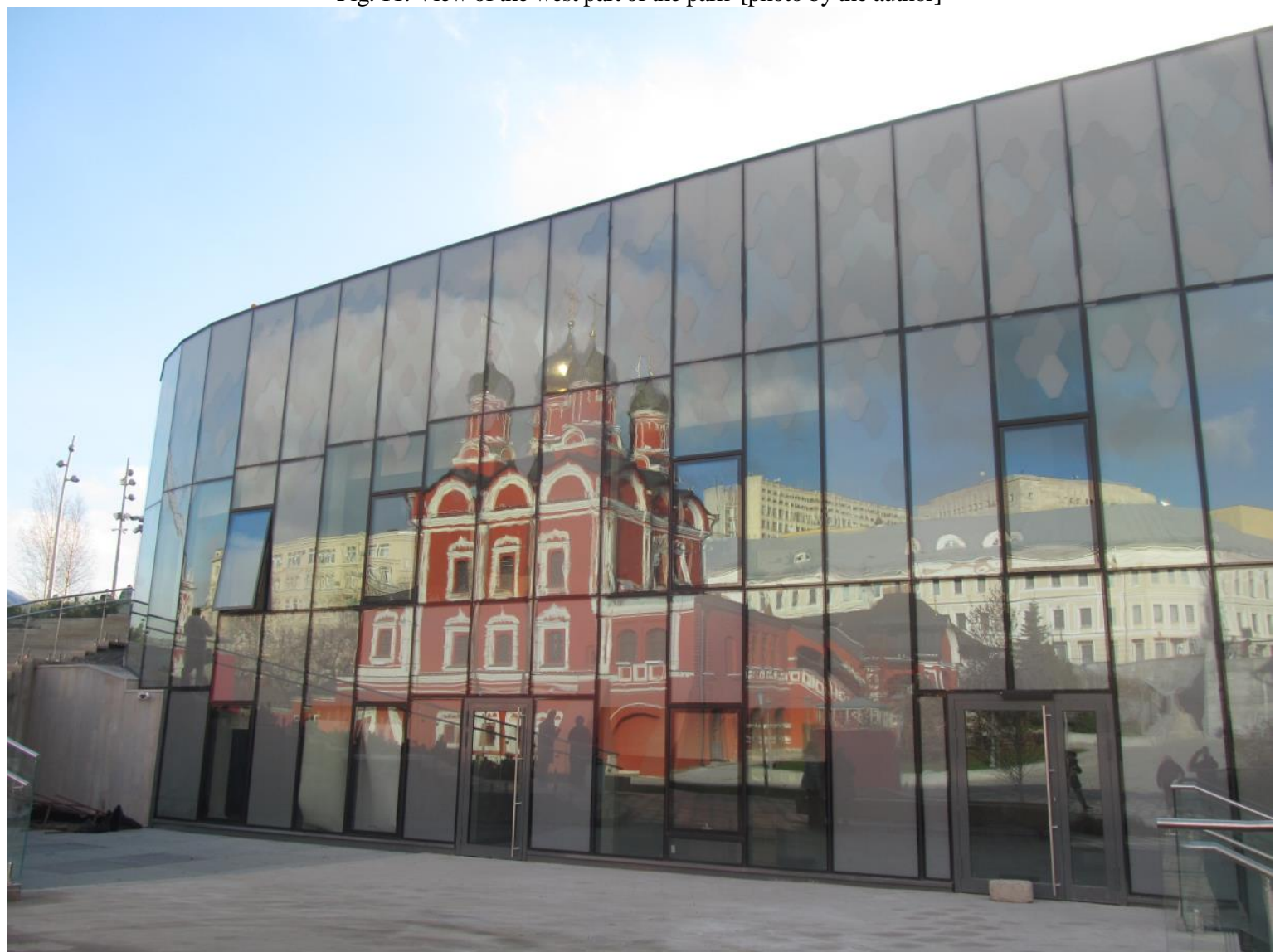

Fig. 12. Reflections of the Znamensky Cathedral in the glass facade constructions of the park [photo by the author] 
with a temperature $-5^{\circ} \mathrm{C}$ inside it. For the formation of the ice, 70 tons of water and a week for its freezing were required. The cave framework is made of seven layers of fiber-reinforced concrete, which includes a large number of fine elastic fibers that reinforce the entire layer, as well as chemical additives to increase plasticity. The northern flora and fauna will be shown with the help of video projections and voice-over text. For one hour, 130 people which in the warm season will receive special mantles, can visit the glacier to inspect the exposition [17].

One of the main attractions in "Zaryadye" is a unique "Soaring Bridge" (Fig. 8), pedestrian overpass in the form of the letter "V" with a 70-meter console without a single support. The bridge supports are installed in the park, and the console with a viewing platform hangs over the Moskva-river at an altitude of about 14 meters. Thus, the effect of soaring over the river is created.

At the same time, 3-4 thousand people can be on the bridge; the structure can withstand a weight of more than 240 tons. The weight of the bridge itself is 3,700 tons. The total length of the bridge is 244,4 meters; The length of the outboard console without supports is 69 meters [16]. The bridge consists of two reinforced concrete beams. In addition to concrete, metal structures and glass are actively used. The bearing structure of the bridge is made of concrete, from below and on the sides "Soaring Bridge" is lined with stainless steel, and the flooring is wooden.

The most large-scale construction of "Zaryadye", one of its dominants is the "Glass Crust" (Fig. 9) a curvilinear spatial covering formed by glass triangles enclosed in a metal frame. With its glass facade, the building is facing towards Kitay-Gorod, and behind it gradually passes into a hill on the slope of which is a big amphitheater. The amphitheater covered with the "Glass crust" is the highest point of the park. Wood-metal frame of glass triangles (Fig. 10) covers about a hectare of territory. This is the world's largest translucent structure without enclosing walls, which protects visitors from the rain and wind. The use of energy-saving technologies allows maintaining a higher temperature than in the open air, even in winter: 150 solar batteries are installed in the southern part of the "Glass crust". The photocells are integrated into the triplex of the double-glazed windows, which fill the cells of the cover; at the same time, the photocells do not occupy the whole area of the glass unit and retain the transparency effect of the "Glass crust", under which one of the main sites of the park is located. The only wall covering the structure is located on the east side, where the "Glass Crust" adjoins the concert hall. Inside, the engineering systems for supplying warm air in winter are installed, as well as for cooling and humidifying the air in summer heat. To operate the structure in winter, there is a system of snow melting and a safety system for climbers who will clean the roof of the snow. Year-round green plants will be under the "Glass crust".

Under the "Glass crust" two transformable halls: a large (for 1560 people) and small (for 400 people), as well as a studio for sound recording, are disposed [17]. The concert platform will be multifunctional. It will sound not only symphonic music, but also variety and jazz concerts. Philharmonic is a closed room with transformable parterre, stage, orchestra pit of the main concert hall.

The underground museum "Zaryadye" has interactive show-windows. In the transition from the park to the embankment one can see a fragment of the Kitay-Gorod wall of the XVI century, customs seals and coin treasures, in the glass window - fragments of the pavement of the ancient Moscow street, Velikaya, at the stands - ancient weapons and horse equipment [13]. There is also a gastronomic centre "Zaryadye", which includes cafes and restaurants (Fig. 11).

Lanterns designed unusual, for illumination of landscape zones, 460 lamps were installed. In the busiest parts of the park, the main light sources are 140 lanterns with a height of 6 to $13 \mathrm{~m}$. The brightness and colour of the lighting in all park lights can be changed depending on the time of day and weather, for example, during rain and fog, the lanterns are brighter [18]. In the grass cover of the park, numerous light windows have been made, illuminating the underground rooms. Underground parking is designed for more than 400 cars. Facades of some buildings are covered with wavy mirror material (Fig. 12), giving them a low-key and somewhat ephemeral look.

The park is surrounded by historical temples and gardens, including the "Old English Court" Museum. It should be noted that the panorama of the historical Varvarka street, in which many historical objects were preserved, became interestingly opened. Along the Varvarka, old churches have been restored: the cathedral, bell tower and buildings of Znamensky Monastery (XVII century), the churches of Great Martyr Varvara (XVIII century), Saint Maximus the Blessed (XVII century), Saint George the Victorious (XVII century), Conception of Saint Anne (XVI century) [15]. Nearby are the chambers of the boyar family Romanovs, as well as remnants of the Kitay-Gorod wall. 


\section{Conclusions}

"Zaryadye" park is the first large-scale object of urban landscape design in Russia. With the opening of "Zaryadye", discussions between supporters and opponents of the project broke out with a new force, remaining opponents in the minority.

Concern for the health of outdoor places is a central theme in landscape architecture integrating natural and manmade worlds. Generally, the task of humanizing the local space has been solved using contemporary tools. This large-scale project integrated various modern trends directed towards the development of sustainable and ecological landscape architecture.

In general, the project is implemented at a sufficiently high level. An unexpected and interesting architectural landscape experiment was obtained. Undoubtedly, in Russia the first most serious attempt was made to create a landscape architectural object of world level.

\section{References}

1. Alexander C.W., Ishikawa S., Silverstein M., Jacobson M., Fiksdahl-King I., Angel S. A Pattern Language: Towns, Buildings, Construction. Oxford University Press, USA. 1977. 1171 pp. ISBN 978-0-19501-919-9

2. Diller Scofidio + Renfro index [online 30.10.2017] https://dsrny.com/

3. Casa de retiro espiritual [online 31.01.2018] http://casaderetiroespiritual.com/index.php

4. Etherington R. Russian Pavilion at the Venice Architecture Biennale 2012 [online 30.10.2017] https://www.dezeen. com/2012/08/29/russian-pavilion-at-venice-architeture-biennale-2012/

5. Laurie M. An Introduction to Landscape Architecture. American Elsevier Publishing Company, Inc., 1975. 214 pp. ISBN13: 978-0-44400-171-9

6. Simonds J.O. Landscape Architecture: The Shaping of Man's Natural Environment. McGraw-Hill Book Company, Inc. 1961. 244 pp.

7. Steele J. Sustainable Architecture: Principles, Paradigms and Case Studies. New York: McGraw-Hill. 1997. 288 pp. ISBN 978-0-07060-949-7

8. The High Line all phases [online 30.10.2017] https://dsrny.com/project/high-line

9. Thompson W., Sorvig K. Sustainable Landscape Construction. A Guide to Green Building Outdoors. Second Edition. Island Press: Washington, Covelo, London. 2008. 412 pp. ISBN 978-1-59726-142-5

10. Ulam A. In Putin's Moscow, an Urban Wilderness Emerges [online 30.10.2017] https://www.citylab.com/design/ 2017/05/in-putins-moscow-an-urban-wilderness-emerges/526872/

11. Vetsch Architektur vetsch architektur [online 31.01.2018] http://www.erdhaus.ch/

12. Zaryadye Park [online 30.10.2017] https://dsrny.com/project/zaryadye-park

13. Бычкова Е. Где укрылось племя вятичей? В «Зарядье» можно погрузиться в глубину веков [online 30.10.2017] http://www.aif.ru/realty/city/gde_ukrylos_plemya_vyatichey_v_zaryade_mozhno_pogruzitsya_v_glubinu_vekov

14. Волкова С. «Зарядье» - это страна в миниатюре [online 30.10.2017] https://stroi.mos.ru/articles/zariad-ie-etostrana-v-miniatiurie

15. Волкова С. Парк «Зарядье» в Москве: 5 особенностей парка, ради которых в нем стоит побывать [online 30.10.2017] https://www.msk.kp.ru/daily/26729.5/3755819/

16. Завершнева О. Строители рассказали, как возводили парк «Зарядье» [online 30.10.2017] https://stroi.mos. ru/articles/glazami-stroitieliei-kak-sozdavali-park-zariad-ie

17. Зарядье: парк настоящего будущего [online 30.10.2017] http://www.zaryadyepark.ru/

18. Никитская Е. «Зарядье»: настоящий парк будущего [online 30.10.2017] http://www.mk.ru/moscow/ 2017/09/13/zaryade-nastoyashhiy-park-budushhego.html

19. Парк «Зарядье» - новый символ Москвы [online 30.10.2017] http://www.zaryadyepark.ru/smi/park-zaryadenovyy-simvol-moskvy/ здесь много всего

20. Сытин П. В. Из истории московских улии. Москва: Московский рабочий, 1958, с. 67.

21. Уриханян А. С южных гор до северных морей [online 30.10.2017] http://portal-kultura.ru/articles/moskva/ 140223-s-yuzhnykh-gor-do-severnykh-morey/

\section{INFORMATION ABOUT AUTHOR:}

Kasyanov Nickolay Vladimirovich. Born in 1973, Leningrad. Educational background: 1993-1999 Architectural Institute of the Far Eastern State Technical University (Arch IDVGTU), now part of the Far Eastern Federal University), diploma with honors. 1999-2002 the postgraduate program. Since 2004 a candidate of architecture. Employment: 1999-2004 the teaching staff, Arch DVGTU, Vladivostok. Since 2004 - Senior Research Fellow, Scientific Research Institute of Theory of Architecture and Urban Planning (NIITIAG), Moscow. Since 2006 - Head of Lab of Architectural Form Creation, NIITIAG. The author of more than 60 published works, with experience of design works. Scientific interests: form creation in architecture and nature, innovative technologies in architecture, fortress architecture. 111024 Moscow, Dushinskaya str., 9, tel/fax +7 (499) 95182 72, phone 891513879 72. E-mail: kas_nv@mail.ru

Kopsavilkums. Rakstā tiek aplūkota parka Zarjadje (Парк «Зарядье») teritorija, kas ir kā viens no pēdējiem liela mēroga ainavu arhitektūras projektiem Maskavas vēsturiskajā centrā. Parks veidots kā inovatīvs piemērs, kas ietver mūsdien̄̄gus risinājumus un ir kā izziņas teritorija gan ainavu arhitektiem, gan pētniekiem. 